\title{
Küreselleşme Paradigması ve COVID 19 Krizinde Medya Üzerine Bir Değerlendirme
}

\author{
DOI: $10.26466 /$ opus.795725
}

\author{
Marco Boschele* \\ * Dr. Öğretim Üyesi/Kocaeli Üniversitesi, İdari ve İktisadi Bilimler Fakültesi, Kocaeli/Türkiye \\ E-Posta: $\underline{\text { m.boschele@yahoo.co.uk }}$ \\ ORCID: $\underline{0000-0003-2498-0317}$

\section{$\ddot{O} z$}

Covid-19 krizi, "küreselleşme paradigmasının" zayıf yönlerini açı̆̆a çıkarmıştır. Bu zayıflıklar, ulusdevletlerin süregelen öneminin "hafife alınması" ve tartışmaların ve politikaların "ulus-sonrası (postnasyonel)" ve dolayısıyla küresel hale gelme boyutunun "gereğinden fazla önemsenmesidir" (Flew, 2020, s.1). Covid-19 krizi ve halk sağlı̆̆ı açısından yapılan müdahaleler, modern tarihin uluslararası akışlarındaki en büyük ve en hızlı düşüşe neden olmuş, ve küresel dünyanın bir tezahürü olarak küreselleşmenin güçleri nedeniyle, tüm dünyaya yayılan kriz, bir yandan olası küreselleşme karşıtlığı konusunda milliyetçi duyguları artırırken, bir yandan da krizin üstesinden gelinmesinde bir panzehir görevi gören kamusal tartışmalarda, çok tarafllık savunucularına yeniden hayat vermiştir. COVID-19 krizinde medyada yer alan haberler, ulusal ve uluslararası siyaseti daha da kutuplaştırmaya ve genel bir panik havası yaratmaya neden olmuştur. Virüsün insan sağllğı üzerindeki etkisinin 24 saatte bir kitlelere media yoluyla bildirilmesi, medyanın uluslararası ilişkilerdeki kritik gücünü odak noktası haline getirmiştir (Pastreich, 2020, s.2). Bir değerlendirme çalışması olan bu yazıda, ilk olarak küreselleşme ile COVID-19 arasındaki ilişkiyi, daha sonra Covid-19 virüsünün küresel değer zincirleri tarafından tüm dünyaya yayılması ve küreselleşme süreci üzerindeki etkisini ele alınacaktır. Daha sonra, pandeminin; küreselleşme karşıtllğ̆l veya yerel ve ulusal ekonomilerin güçlenmesiyle, nasıl bir ilişki içerisinde olduğunu tartışılacaktır. Son olarak, Avrupa ve Amerika Birleşik Devletleri medyasının Covid-19 krizini aktarırken siyasi kutuplaşmayı nasıl artırdığını ve bilgilendirici ve eğitici bir bilgiye sahip olmayı nasıl zorlaştırdığı incelenecektir.

Anahtar Kelimeler: kürelleşme, COVID 19, medya, milliyetcilik, popülizm, Avrupa, Amerika 


\title{
The Globalization Paradigm and the Media in the COVID 19 Crisis
}

\begin{abstract}
The Covid 19 crisis has exposed the weaknesses of the "globalization paradigm". These weaknesses are the "under-estimation" of the enduring importance of nation-states and the "over-estimation" of "the extent to which debates and policies have become 'post-national' and therefore global" (Flew 2020, s.1). While the Covid 19 crisis and the required public health measures dictated by the governments are producing the largest global economic impasse ever seen in modern history, the crisis, as a manifestation of the global world, spreading worldwide due to the forces of globalization, has both increased nationalist sentiments about potential de-globalization but also revitalized proponents of multilateralism in public debates as an antidote to tackle the crisis. In the COVID-19 crisis, the media coverage have helped to further polarize national and international politics and to create a general panic. The 24 hours reporting of its impact have placed "the critical power of the media" in international relations into scrutiny (Pastreich, 2020, s.2). In this evaluative study, first it will be considered the relationship between globalization and COVID-19 in terms of its developments after the end of the Cold War and in terms of its relation the Covid-19 virus has been transmitted worldwide by global value chains and its effect on the process of globalization. Thereafter, it will be considered how the pandemic has entangled with the deglobalization or the strengthening of local and national economies. Finally, it will explore how the media in Europe and the United States in covering the Covid 19 crisis have increased political polarization making it difficult to have an informative and educational information.
\end{abstract}

Keywords: Globalization, COVID 19, media, nationalism, populism, Europe, USA 


\section{Giriş}

İkinci Dünya Savaşı'ndan bu yana yaşanan en büyük küresel sağlık krizi olan Koronavirüs COVID-19 pandemisi, Antarktika dışındaki tüm kıtalara yayılmıştır. Bu denli bir sağlık krizi, dünya genelinde eşi benzeri görülmemiş bir sosyo-ekonomik krize neden olmakla birlikte, derin ve kalıc travmalar bırakacak yıkıcı sosyal, ekonomik ve politik etkiler yaratmaktadır. Covid-19 krizi, "küreselleşme paradigmasının" zayıf yönlerini de açığa çıkarmıştır. Bu zayıflıklar, ulus-devletlerin süregelen öneminin "hafife alınması" ve tartışmaların ve politikaların "ulus-sonrası (post-nasyonel)" ve dolayısıla küresel hale gelme boyutunun "gereğinden fazla önemsenmesidir" (Flew, 2020, s.1). Bir yandan küreselleşme, bireyleri ve birey gruplarını şimdiye kadar var olmayan iletişim biçimleri aracılığıyla birbirine bağlayarak ulus devletin geleneksel rolünü krize iterken, öte yandan, bu devletlere hayat veren ulusal gruplar, kendi siyasi sınırlarını çeşitli şekillerde korumaya çalışmaktadırlar (Gaddedu, 2019, s.1). Covid-19 krizi ve halk sağlığı açısından yapılan müdahaleler, modern tarihin uluslararası akışlarındaki en büyük ve en hızlı düşüşe neden olmuş, ve küresel dünyanın bir tezahürü olarak küreselleşmenin güçleri nedeniyle, tüm dünyaya yayılan kriz, bir yandan olası küreselleşme karşıtlığı konusunda milliyetçi duyguları artırırken, bir yandan da krizin üstesinden gelinmesinde bir panzehir görevi gören kamusal tartışmalarda, çok taraflılık savunucularına yeniden hayat vermiştir.

Küresel bir salgın şeklindeki ortak bir düşman, kutuplaşmış demokrasileri bir araya getirebilir mi? Liderler ve vatandaşların bu firsatı değerlendirerek birlikteliklerini güçlendirmelerinin bir yolu var mı? Fiziksel sağlık, ekonomik refah ve ulusal akla yönelik varoluşsal bir tehdit oluşturan küresel bir pandemi, ulusal dayanışmanın inşa edilmesinde mükemmel bir ortak düşman gibi görünebilir. Bununla birlikte, ilgili psikoloji literatürü, insanların bir hastalığa karşı verdikleri tepkilerin insan olan düşmanlara verdiklerinden farklı olabileceğini öne sürmektedir. İğrenme ve enfekte olma korkusu, insanları tanıdık kişilerle temas etmeye yönlendirir ve azınlık gruplara dahil yurttaşlar da dahil olmak üzere sözde yabancilara karşı olan önyargıları tetikler (Quarcoo ve Kleinfeld 2020, s.1). Örneğin, kara veba, ortaçağ Avrupa'sında binlerce Yahudi'nin katledilmesine yol açmış, yirminci yüzyılın başlarında San Francisco'da yaşanan kolera salgınları, Çin karşıtı ayrımcılığa yol 
açmış, 2014 Ebola krizi ise Afrikalılara yönelik önyargıyı artırmıştır. Günümüzde, yaşanan bir halk sağlığı felaketinin suçlularını bulma arzusu, nefret suçları ve yabancı düşmanlığında da küresel oranda artışlara yol açmıştır (Quarcoo ve Kleinfeld 2020, s.2).

Bu senaryoda, medyanın üstlendiği yeni rolün yani siyasi kararların alınmasında önemli bir payı olduğu bir çağda, genel olarak haber medyası ve gazetecilik, kamuoyuna doğru, bilimsel ve objektif bilgi sunmada önemli bir role sahiptir (bkz. Brexit ve Trump seçimi 2016) ve etraflarındaki genel siyasi atmosfer, 'post-truth' siyaset olarak nitelendirilmektedir. COVID-19 krizinde medyada yer alan haberler, ulusal ve uluslararası siyaseti daha da kutuplaştırmaya ve genel bir panik havası yaratmaya katkı sağlamıştır. Virüsün insan sağlığı üzerindeki etkisinin kitlelere 24 saatte bir medya yoluyla bildirilmesi, medyanın uluslararası ilişkilerdeki kritik gücünü odak noktası haline getirmiştir.

Bu makalede, ilk olarak küreselleşme ile COVID-19 arasındaki ilişki, daha sonra Covid-19 virüsünün küresel değer zincirleri tarafından tüm dünyaya yayılması ve küreselleşme süreci üzerindeki etkisi değerlendirilecektir. Daha sonra, pandeminin; küreselleşme karşıtlığı veya yerel ve ulusal ekonomilerin güçlenmesiyle nasıl bir ilişki içerisinde olduğu kuramsal analizlerle tartışılacaktır. Son olarak, Avrupa ve Amerika Birleşik Devletleri medyasının Covid19 krizini medya yoluyla kitlelere aktarırken, siyasi kutuplaşmayı nasıl artırdığı ve medyanın virüs konusunda bilgilendirici ve eğitici bilgiye sahip olmayı nasıl zorlaştırdığı incelenecektir.

\section{Küreselleşme ve Covid-19}

1990'ların başında, Sovyetler Birliği'nin çöküşü ve Soğuk Savaş'ın sona ermesiyle birlikte küreselleşme süreci hız kazanmıştır. Bunun yanı sıra, uluslararası büyümede, yatırımlarda ve küresel insan hareketinde artışa da tanık olduk; internetin ve küresel dijital iletişim ağları yükselişe geçti; uluslararası kanun, antlaşma ve anlaşmaların sayısında da bir artış gerçekleşti. Manuel Castells (1996) bu gelişmeleri; çevresel bozulma, iklim değişikliği, terörizm ve insan hakları gibi küresel sorunların üstesinden gelmek için tasarlanmış olan "küresel ağ toplumu" olarak adlandırmıştır. Küresel ağ toplumu, uluslararası sivil toplum hareketlerinin ve uluslararası hükümet ve sivil toplum kuruluş- 
larının (STK'ların) ortaya çıkmasına yol açmıştır. Ulus-devletlerin egemenliğinin dönüştürülmesinde bu kuruluşlar, önemli rol oynamışlar, böylece etkili siyasi güç, giderek daha "ulusal, bölgesel ve uluslararası düzeylerde çeşitli güçler ve kurumlar tarafından paylaşılmış ve takas edilmiştir" (Flew, 2020, s.3).

Covid-19 virüsünün küresel değer zincirleri ve hava ulaşımı yoluyla, dünya çapında bulaşması ve bununla mücadele etmek için uygulanan politikalar, organize insan yaşamının birçok yönü ile birlikte, bu uluslararası ortamları ve çerçeveleri etkilemiştir. Esasen, Covid-19; hizmet ekonomileri, küresel kültür ve yaşam tarzlarının temel özellikleri olan doğrudan temas ve yüz yüze etkileşim yoluyla yayılmıştır. Dahası, virüse çare bulunmasının imkânsızlığı göz önüne alındığında, eldeki seçeneklerin "sürü bağışıklığı" veya Darwinici bir politika ya da ekonomiyi durdurarak ve karantina uygulayarak, sosyal ve ekonomik etkileşimlerin kapatılması olduğu görünmekte olup; ikinci seçeneğin en yaygin seçenek olduğu artık kanıtlanmıştır.

Bu şekilde salgın, dünyanın her köşesinden "küresel değer zincirlerinin" (küresel değer zincirleri: küresel malların ve hizmetlerin üretiminde ve tedarikinde ve dağıtımındaki insanlar ve etkinlikler OECD) sağladığı hizmet ve ürünlerin tüketimi yoluyla, ihtiyaçları karşılama biçimini de sekteye uğratmaktadır. Bu gelişmeyle birlikte, birçok şirket ve ulus devlet daha sonra stratejilerini yerel ve bölgesel seçeneklere doğru yöneltmiştir. Bu değişiklikler, mal ve hizmetlerin serbest ticaretinin düzenlenmesine ilişkin kuralları ve insanların, işçilerin hareketliliğini etkilemiştir. Bunların yanı sıra, pandemi vatandaşların denetlenmesine yönelik ulusal mekanizmaları da hayata geçirmekte ve böylece insanlar iş veya tatil amacıyla ulusal sınırların dişına çıkma konusunda tereddüt etmektedirler (Dimoulas, 2020, s.10).

Başka deyişle, pandemi sıkı bir işbirliği için fırsat gibi görünse de; Çin, Amerika Birleşik Devletleri, Avrupa Birliği ve Rusya arasında bir birlik ortamı oluşmasını sağlamamıştır. Covid-19'a karşı birlik olunamaması, somut olmayan bir virüse karşı birleşmenin zor olduğunu ve/veya yaptırımlar, savaşlar, ve silahların kontrolü konusundaki farklılıkları gözler önüne sermektedir. Uluslararası arenadaki başlıca aktörler, salgını siyasi ve ideolojik çatışmalarında bir araç olarak kullanmakta ve ulusal tıp bilimi komiteleri de virüse karşı birleştirilmeye çalışılmaktadır. 
Esasen, küreselleşme karşıtı akımın ve milliyetçiliğin artışı, salgından önce başlamıştır. Trump'un izolasyonist pozisyonu, Obama'nın ABD'nin denizaşırı taahhütlerini kısma stratejisine benzer niteliktedir. ABD, neo-izolasyonizminin geleceği, biçimi ve ölçeği, pandemiden ziyade, onun yaklaşan başkanlık seçimlerinin sonuçları üzerindeki etkisine bağlı olacaktır. $\mathrm{Bu}$ arada, küreselleşmenin liderlerinden biri olarak, ABD'nin rolünün azalacağı gayet iyi bilinmektedir (Alexandrova-Arbatova, 2020, p.6). Ulusal düzeyde salgınlara çare bulmaya yönelik her türlü çabanın, uluslararası işbirliği amaçlı kullanılmaktan ziyade, seçimlerde ve uluslararası prestij kazanmada siyasi bir araç olarak kullanılacağı da, açık ve net olarak görünmektedir.

\section{Ulus Devlet ve Siyasi Kutuplaşma}

2016'dan bu yana, uluslararası iki olay küresel düzeni bir şekilde etkilemiş ve küreselleşme karşıtlığ sürecini hızlandırmıştır. Bunlardan ilki, az bir çoğunluğun 40 yıllık üyeliğin ardından Avrupa Birliği'nden (AB) ayrılmayı tercih ettiği Birleşik Krallık'taki Brexit referandumudur. İkincisi ise, Donald Trump'ın Demokrat aday Hillary Clinton yerine, ABD'nin 45. Başkanı olarak seçilmesidir. Bu seçim sonuçları, Avrupa ve dünyadaki liberal demokrasilerde meydana gelen daha geniş bir popülist dalganın parçası olarak kabul edilmektedir. Bu artış, küreselleşmenin ekonomik, sosyal ve kültürel sonuçlarına ve ortak küresel zorlukları ele alınmasında, seçkin küresel güçlerin yaşadığı krize karşı gerçekleşmiştir (Flew, 2020, s.2).

Böyle bir ortamda, Covid-19 krizi ve ulus devletin ve uluslararası toplumun bununla başa çıkmak için verdiği tepki, küresel neoliberal düzenin ne kadar zayıf olduğunu bir kez daha göstermiş ve neoliberal küreselleşmeye yönelik hoşnutsuzluğun var olduğunu doğrulamıştır (Dimoulas, 2020) . Küreselleşme savunucularının aksine, salgın, ulus devletin dirençli olduğunu ve aynı zamanda ortak sosyal sorunların yönetimi için tercih edilen kurum olduğunu göstermektedir. Bu durum, büyük bir krizde önceliğin ulusal boyutta olduğunu göstermektedir. Örneğin, pandeminin ilk aylarında Avrupa devletleri, ortak bir politika izlemeden sınırlarını kapattılar (Alexandrova-Arbatova, 2020, s.10). Hükümetlerin ulusal kurumları tercih etmesi, ulusal yetkilerin ötesinde yasama yetkisine sahip uluslararası kurumların güçlendirilmesi talebine karşı çıkıldı̆̆ının göstergesidir. 
Koronavirüs krizi bu suretle, zaman zaman zaten devam eden bazı eğilimlerin pekişmesini sağlamıştır. Ayrıca, Avrupa'daki hükümetler arasında siyasi kutuplaşma da ortaya çımıştır. Fransa'da Emmanuel Macron, partisinden bazı üyelerin "toplumsal eşitsizliklere karşı" daha cesur ve daha agresif eylemler yapmaya odaklanan yeni bir grup oluşturmak amaciyla ayrılmasıyla birlikte, parlamentodaki çoğunluğunu kaybetmiştir. Pandemi öncesinde, Macron'a verilen destek, oldukça düşüktü. Fransa'nın virüse karşı katı şekilde uyguladığı sokağa çıkma yasağı, Fransız siyasi manzarasını etkilemiştir. Zaruri olmayan işletmelerin kapatılması ve test kabiliyetini artırma konusunda Avrupa'daki diğer birçok ülkeye nazaran daha fazla beklemesinden dolayı, İngiltere'nin virüse tepkisi de pek çok kişi tarafından yavaş olmakla eleştirilmiştir (Rizzi, 2020).

Avrupa'daki muhalefet partileri de bu krizin nasıl daha iyi idare edilebileceğine dair yoğun anlaşmazlıkların olması nedeniyle, seslerini daha yükselteceklerdir. Bazı durumlarda, aşırı sağ siyasi partilerin protestolara pek destek vermedikleri veya onlardan yararlanmaya çalıştıkları bildirilmiştir. Protestolara katıldıkların inkar etseler de, bu partiler genellikle protestocuların eylemlerini tartışmasız bir şekilde kınamayı reddetmişlerdir. Bu tür protestoların çoğu sağci-milliyetçi bir yönde gerçekleşmiştir.

Avrupa'da sokağa çıkma yasağının kaldırılmasıyla ilgili tartışmaların dikkat çekici bir özelliği de, sağ partilerin birçoğunun demokrasiyi yeniden inşa etme söylevini benimseme biçimidir. Almanya'da aşırı sağcı Almanya için Alternatif (AfD) Partisi, vatandaşlık haklarına getirilen kısıtlamaların mümkün olan en kısa sürede kaldırılması çağrısında bulunmuştur. İtalya'da aşırı sağ cı Lig partisi lideri Matteo Salvini, “özgürlüklerin tam olarak yeniden getirilmesi" için baskı yapmak amacıyla, bir aşamada ülkenin parlamentosunu işgal ederek üst düzey birçok gösteri ve protesto eylemi gerçekleştirmiştir. Hollanda'da sağcı Özgürlük Partisi (PVV) ve Demokrasi Forumu, siyasi k1sttlamaların vakit kaybedilmeden hafifletilmesi konusunda en güçlü baskıyı yapan partiler olmuştur. PVV Lideri Geert Wilders, hükümetin koronavirüs stratejisini bireysel özgürlükleri korumadığı için eleştirerek, katı bir çizgide söylemlerini devam ettirmiştir (Hípola ve Padilla, 2020).

Avusturya'da sağcı Özgürlük Partisi, hükümeti koronavirüsle ilgili kısıtlamalarda çizgiyi aşmakla suçlamıştır. Parti, hükümeti, koronavirüse yakalanan kişilerin temas ettiği bireyleri izleyen uygulamaları kullanmaya ve va- 
tandaşları kendi özel alanlarında fiziksel mesafe kurallarına uymaya çağırmaya zorlamasından dolayı, ülkenin anayasasını ve vatandaşların haklarını ihlal etmekle suçlamıştır. Aşırı sağcı İspanyol Vox partisi de benzer bir şekilde kavgacı bir duruş benimsemiştir. Liberal olmayan, otorite yanlısı bu parti, İspanya'nun Sosyalist İş̧̧i Partisi önderliğindeki hükümeti devirmek amacıyla, açık demokrasi söylemini beceriksizce bu amaçla kullanmıştır (Youngs, 2020, .2). ABD'de Donald Trump, kamuoyu önünde demokrat eyaletlerin özgürleştirilmesi ve valilerinin baskıcı önlemlerden vaz geçmesi çağrısında bulunmuştur. Ancak, insanların Trump'ın krizi ele alış biçimine dair algısı, salgın öncesindeki düşünceleri tarafından şekillendirilmiştir. Çoğu Cumhuriyetçi Trump'un tarzını onaylarken, Demokratlar bu tavrı reddetmekte ve başarısızlık olarak görmektedirler (Hípola ve Padilla, 2020).

Hindu çoğunluğun bulunduğu Hindistan'da, salgının ilk patlak vermesinin İslami bir misyonerlik etkinliğine kadar izini süren bazı haber kaynakları, koronavirüsün neden olduğu hastalık olan COVID-19'dan dolayı, Müslümanları suçlamıştır. Bu arada, Brezilya Devlet Başkanı Jair Bolsonaro'nun salgının ciddiyetini kabul etmemesi, ülkenin ideolojik ayrımlarını daha da keskinleştirmiştir. Bolsonaro, çoğu vali, kongre lideri ve hatta kendi sağlık bakanı da dahil olmak üzere, artan enfeksiyon oranlarından kaygı duyan ülkedeki geniş kitleleri ötekileştirirken, tabanındaki destekçilerini harekete geçirmiştir (Quarcoo ve Kleinfeld, 2020, s.1).

Güvensizlik ortamı kendini farklı şekillerde gösterir. İnsanlar, hükümet görevlilerinin kurallara uymadıkların düşündüklerinde, bu kuralları kendileri uygulama ve gereken her şekilde kendi çıkarlarını gözetme olasılıkları daha fazladır. Bazı ülkelerde bu, stokçuluk, karaborsa ve organize suç olarak kendini gösterir (suç örgütleri, sahte tıbbi malzeme ve nadir bulunan diğer malların uluslararası satışını hâlihazırda yapmaktadır.). Bu güvensizlik duygusu, diğer toplumlarda yasadışı şiddet veya sosyal mesafe kurallarını kitlesel olarak çiğnenmesi şeklinde tezahür edebilir (Quarcoo ve Kleinfeld, 2020, s.4). Pandemi, birçok ülkede ulusal birlik duygusu üzerinde bölücü bir etki yaratmıştır.

Ekonomisi gelişmiş 14 ülkenin hükümetinin koronavirüs salgınını nasıl ele aldığının araştırıldığı bir ankette, vatandaşların ortalama \%46'sı şu an koronavirüs salgını öncesine göre ulusal birliği daha fazla hissederken, \%48'i ise bölünmelerin büyüdüğünü düşünmektedir. Bu oran, pandemiden öncekine göre daha fazla bölünmüş olduklarını söyleyen Amerikanların \%77'sini ifade 
ederken, Amerikanların yalnızca \%18'i ülkenin daha da birleştiğine inanmaktadır. Ayrıca, bu insanların ortalama \%58'i, COVID-19 nedeniyle hayatlarının büyük ölçüde veya oldukça ciddi bir şekilde değiştiğini ifade etmişlerdir. Virüsün etkilerini en şiddetli şekilde hissedenler özellikle kadınlar olmuştur (Connaughton ve Devlin, 2020).

Bu duygusal kutuplaşmanın sonucu olarak, seçtikleri siyasiler tarafından teşvik edilen seçmenlerin bir kısmı, bilimsel otoritelere güvenmemeye başlamıştır. İklim değişikliğine karşı önlemler alma konusunda cumhuriyetçi seçmenlerin şüpheciliği ile kısmen açıklanabilen bu durum, bu seçmenlerin davranışlarını değiştirmektedir. Diğer araştırmalar, pandeminin ilk haftasında vatandaşın davranışını en iyi açıklayan faktörün siyasi tercihleri olduğunu göstermiştir. Dünya Sağlık Örgütü direktörü Tedros Adhanom Ghebreyesus'un sözleriyle sonuç gayet açıkça görülmektedir: “Daha fazla ceset torbası istemiyorsanız, bunu politize etmekten kaçınacaksını" (Hípola ve Padilla, 2020).

\section{Medya, Siyaset ve COVID-19}

Kitle iletişim araçları, uzun zamandır dünyayı ve insanların kendilerini deneyimleme biçimini şekillendiren etkili güçler olarak kabul edilmektedir. Koronavirüs paniği ve medyanın hiçbir bilimsel analize dayandırmaksızın kamuoyuna sunduğu yalan- yanlış haberler, küresel işbirliği için fırsat olabilecek bu krizi, havalimanlarını durma noktasına getiren ve hisse senedi piyasalarının çökmesine neden olan küresel ekonomik bir yıkıma dönüştürmüştür.

Dahas1, Amerika Birleşik Devletleri'nin dünyanın lider gazetecisi olarak sahip olduğu egemenlik, ABD medyasının zayıflıklarının dünya medyasının zayıflıkları haline geldiği anlamına gelmiştir. Birleşik Devletler'de yıllardır süren liberalleşmeler, büyük şirketlerin kontrolü altında bulunan medya kaynaklarının sayısını artırmış, yerel gazeteleri ve bağımsız istasyonları yarışın dışında bırakmıştır. 1980'lerde başlayan de-regülasyon politikaları, habercilikte kamu hizmeti sorumlulukları ortadan kalkmış, gazete ve dergiler uzun zamandır çalıştıkları personellerini işten çıkarmış, bu durum, neredeyse tüm dünyaya yayılmıştır (Pastreich, 2020, s.1). Artık pek çok ülkede medyanın halkı eğitmek için bir araç değil, bir kâr kaynağı olduğu kabul edilmektedir. 
Koronavirüs hakkında sürekli haber yapılması, diğer haberlerin bir kenara itilmesine neden olmuştur. Silahlı şiddet, intihar veya diğer birçok hastalıktan dolayı ölenler haber yapılmamış, hastalıktan ölen her insanın bildirilmesi vatandaşlar arasında demokrasiye uygun politikalar konusunda mantıklı tartışmaların yapılmasını önlemiş, panik ortamını daha da alevlendirmiştir. Milyonlarca insanı öldüren ve daha da fazlasını öldürecek olan çok daha fazla önem arz eden iklim değişikliği tehlikesi, haberlerde yer bulmamaktadır. Benzer şekilde, Birleşik Devletler silah kontrol anlaşmalarından tek taraflı olarak çekilirken ve nükleer silah sistemlerinin iyileştirilmesi için bir trilyon dolara yakın harcama yaparken, artan nükleer savaş tehdidine de haberlerde değinilmemektedir. Bu nedenle, dünyada zenginliğin aşırı bir şekilde belli yerlerde yoğunlaşması, ana akım medya tarafından neredeyse görmezden gelinmektedir.

Medya koronavirüse tam olarak neyin neden olduğu ve nasıl yayıldığı, hastalığın geçirilmesi hakkında gerçek bilimsel nitelikteki haberleri, nispeten nadir olarak yayınlamaktadır. Çünkü medya doğası gereği eğitici olmayı değil, sansasyonelliği ve pazarlamayı hedeflemektedir. Başka deyiş̧le, medya bilimsel içerik ile salgın sürecinin nasıl ilerlediğini açıklamak veya COVID-19 kaynaklı ölümlerin sayısı ile tüberküloz, hepatit $B$ veya pnömoni gibi diğer ölümcül bulaşıcı hastalıklar arasında anlamlı karşılaştırmalar sağlamak amacyyla çok az sayıda, gerçek uzmanı televizyona çıkarmaktadır (Pastreich, 2020, s.3). Başka bir deyişle, kendini ölüm kalım meseleleri hakkında halkı bilgilendirmeye adamış bir medyaya artık her zamankinden daha fazla ihtiyaç vardır. Yeterli şekilde finanse edilen araştırmacı gazetecilik ve kamu yararını kollayan medya kuruluşları olmadan dünya rehbersiz kalacaktır (Pastreich, 2020, s.3).

Edelman tarafından Covid-19 sırasında duyulan güven üzerine yapılan yakın tarihli bir küresel ankete göre, gazetecilerin salgınla ilgili en az güvenilen bilgi kaynağı oldukları, ancak dünya çapındaki nüfusun önemli bir kısmının koronavirüs hakkındaki güncellemeleri köklü ulusal medya aracıllğıla aldığı görülmektedir. 6-10 Mart 2020 tarihleri arasında Brezilya, Kanada, Fransa, Almanya, İtalya, Japonya, Güney Afrika, Güney Kore, İngiltere ve ABD'de toplanan veriler, yüzde 83'lük bir oran ile bilim insanlarının, yeni koronavirüs konusunda en güvenilir bilgi kaynağı olduğunu göstermektedir. İnsanların yalnızca \%43'ü medyayı Covid-19 konusunda güvenilir bulmakta, bu da gazetecileri iş arkadaşlarından, STK temsilcilerinden, politikacılardan 
ve "sizin gibi birinden" daha az güvenilir hale getirmektedir (Connaughton ve Devlin, 2020).

Avrupa Birliği'ndeki medya kuruluşlarına duyulan güven son beş yıldır düşüşe geçmiştir. 2019'da yapılan Ipsos anketi, güven düzeyinin Avrupa'da genel olarak azaldığını, ancak bu göreceli düşüşün etkisinin, ülkeden ülkeye büyük ölçüde değiştiğini göstermektedir. Örneğin, 2014-2019 yılları arasında Almanya'da gazete ve dergilere olan güven \%12 oranında azalmıştır, ancak Almanların \%65'i hala gazetelere güvenmektedir. İspanya'da, insanların $\% 57$ 'si gazete ve dergilere az güvenmekte veya hiç güvenmemektedir, çevrimiçi haber platformlarına duyulan güvensizlik daha da yüksektir (Ferraresi, 2020).

Fransa'da medyaya duyulan güvensizlik, çoğunlukla Sarı Yelekli protestoları hakkındaki haberler ve sıradan vatandaşlar ile Parisli seçkinler arasında giderek büyüyen bir uçurum algısı nedeniyle, ciddi bir şekilde artmıştır. Vatandaşlarının yarısı genellikle gazetecilere güvenen ve diğer yarısı aktif olarak güvenmeyen İtalya, bu güven eğrisinin tam ortasında yer almaktadır. Milliyetçiliğin yeniden canlanması ve Doğu Avrupa'da otorite yanlısı ve liberal olmayan eğilimlerin yayılması, güven endeksinin özellikle Sırbistan ve Macaristan gibi ülkelerde düşmesine neden olmuştur (Ferraresi, 2020).

\section{Tartışma ve Sonuç}

Virüsün bulaşma şekli, küreselleşme süreçlerinin bir sonucudur, ve virüsle ulusal düzeyde titizlikle mücadele etmek için alınan önlemler ise ürün ve hizmetlerin serbest ticaretine dayanan küreselleşmenin temellerini ve insanlar ve çalışanların seyahat özgürlügünü tehlikeye atmaktadır. Bu çelişkili durum, küresel ve yerel arasındaki zıtlığı, gözler önüne sermektedir. Katsourides (2020)' da belirttiği gibi, küreselleşme ve ulus devlet arasındaki mücadele Avrupalı şüphecilerin, popülistlerin ve milliyetçilerin işine yarayacak, göçmenlik karşıtı güçler daha fazla sınır kontrolü talep etmek için uygun bir bölge bulacaktır. Gene bu çelişki, küreselleşme, devlet egemenliği, ekoloji, göç ve $A B$ 'nin rolü bağlamına ilişkin konuları tartışmanın odak noktası haline getirecektir.

Pandemi, medya ve siyaset ilişkisi açısından önemli bir nokta daha vardır. Medya, halka açık toplantılarda bilimsel gerçeklere dayalı endişeleri dile getirmiş, dünya çapında çok sayıda okulu kapatma kararını alarak tarihte eşi 
görülmemiş bir duruma yol açmıştır. Bu durumun tersine, yaz aylarında ise turistik yerler ve çeşitli eğlence yerleri ticarete açılmıştır. Bu durum dikkatli bir biçimde düşünüldüğünde, aynı yöneticilerin kısa aralıklarla bu kararları verebilmesi/değiştirmesi tartışmaya açık bir konudur. Bu tedbir kararlarının çoğu, uzmanlara danışılmadan ve genellikle Dünya Sağlık Örgütü'nün tavsiyelerine aykırı olarak politikacılar tarafından alınmıştır. Çoğu durumda, yasa çıkarılmadan veya meclis komiteleri tarafından tartışılmadan girişilen bu ani politika değişikliklerinin ardında yatan karar alma süreci medya organları tarafından anlatılmamıştır. En önemli konu olan politikanın oluşturulma ve uygulanma süreci, tamamen kamuoyundan gizlenmiştir.

Oysa, medya ve gazetecilik, yanlış bilgi salgınına karşı bir panzehir görevi üstlenmelidir. Çünkü bu olağanüstü koşullar, bir bakıma medya için büyük bir "güven testi"dir. Ancak, Covid 19 salgınıyla birlikte medyanın çoğunun üstlendiği rol, halk arasında panik ortamının yaratılmasına katkıda bulunmuştur. Büyük şirketlerin medya kaynakların kontrol etmesi ve yapıcı bilgi kaynağı olmaktan ziyade, kâr kaynağı haline gelmeleri, güvenilir bilgi kaynağı olmayı zorlaştırmaktadır. Tüm dünyada medyanın halkın güvenini yitirmiş olması, bu eksikliklerin bir göstergesidir. Medya, bu tartışmanın başında da belirtildiği üzere, kriz hakkında haber yaparken, kasten veya kasıtsız olarak, koronavirüse yakalanan veya virüs kaynaklı ölüm vakalarını bir spor müsabakası gibi günlük olarak bildirmek suretiyle ulusal duyguları körüklemiştir. 


\title{
EXTENDED ABSTRACT
}

\section{The Globalization Paradigm and the Media in the COVID 19 Crisis}

\author{
Marco Boschele \\ Kocaeli University
}

The coronavirus COVID-19 pandemic is the major global health crisis since World War Two and it has spread to all continent apart from Antarctica. The extent of this health crisis is causing an unprecedent socio economic crisis and it is also having destructive social, economic and political effects that will leave profound and enduring traumas. The COVID-19 crisis has also exposed the weaknesses of the "globalization paradigm". These weaknesses are the "under-estimation" of the enduring importance of nation-states and the "over-estimation" of "the extent to which debates and policies have become 'post-national' and therefore global" (Flew, 2020, s.1). On the one hand, globalization pushes the traditional role of the nation state into crisis by connecting individuals and groups of individuals through modes of communication that were until now non-existent. On the other hand, national groups animating these states try to defend their own political borders in various ways. While the COVID-19 crisis and the public health policies are affecting negatively international flows in a way that it has never been in modern history, the crisis, as a manifestation of the global world, spreading worldwide due to the forces of globalisation, has both increased nationalist sentiments about potential de-globalisation but also revitalised proponents of multilateralism in public debates as an antidote to tackle the crisis.

It can be argued that the COVID-19 crisis can be seen an opportunity to bring democracies together and to also an opportunity for politicians the and public to get closer. Also, a crisis can be seen as the perfect opportunity to build national unity because of the danger it presents to "physical health, economic well-being, and national psyches" (Quarcoo and Kleinfeld, 2020, s.1). However, psychological studies shows that people may react differently to a disease than to human enemies. Fear of being infected make people to prefer contact with those who are familiar and cause prejudice toward "the other", including citizens who belong to minority groups (Quarcoo and Kleinfeld, 
2020, s.3). In fact, the COVID-19 crisis has already led to a worldwide increases in hate crimes and xenophobia (Quarcoo and Kleinfeld, 2020, s.3).

In this scenario, the news media in general and journalism have an important role in bringing to the public accurate, scientific and objective information in an age where the new role of media has played an important part in political outcomes (see Brexit and Trump election in 2016) and the general political atmosphere around them has been labelled as 'post-truth' politics. In the COVID-19 crisis, the media coverage have helped to further polarize national and international politics and to create a general panic.

In this article, the relationship between globalization and COVID-19 in terms of its developments after the end of the Cold War and in terms of its relation the Covid-19 virus has been transmitted worldwide by global value chains and its effect on the process of globalization will be consider. Thereafter, it will be considered how the pandemic has entangled with the deglobalization or the strengthening of local and national economies. Finally, it will be explored how the media in Europe and the United States in covering the Covid 19 crisis have increased political polarization making it difficult to have an informative and educational information.

\section{Kaynakça / References}

Alexandrova-Arbatova, N. (2020). Global world after the Covid-19 outbreak. IN DEPTH, 17(3) 15 Haziran 2020 tarihinde https://epin.org/wp-content/uploads/2020/05/newsletter.pdf adresinden erişildi.

Gadeddu, D. (2019). State, nationalism and globalization. Glocalism: Journal Of Culture, Politics and Innovation. 18 Haziran 2020 tarihinde https://glocalismjournal.org/wpcontent/uploads/2019/10/editorial gjcpi 2019 2-2.pdf adresinden erişildi.

Connaughton, A. and Devlin, K. (2020, Ağustos 21). Most approve of national response to COVID-19 in 14 advanced economies. Pew Research Center. 15 Ağustos 2020 tarihinde https://www.pewresearch.org/global/2020/08/27/most-approve-ofnational-response-to-covid-19-in-14-advanced-economies/ adresinden erişildi.

Dimoulas, C. (2020). The impact of Covid-19 in South EU Member States and the future of the Monetary Union. IN DEPTH, 17(3). 15 Haziran 2020 tarihinde https://epin.org/wpcontent/uploads/2020/05/newsletter.pdf adresinden erişildi. 
Ferraresi, M. (2020, Nisan 24). As Europe Confronts Coronavirus, the Media Faces a Trust Test. Neiman Reports. 15 Temuz 2020 tarihinde https://niemanreports.org/articles/a-trust-test-for-the-media-in-europe/ adresinden erişildi.

Flew, T. (2020). Globalization, neo-globalization and post-globalization: The challenge of populism and the return of the national. Global Media and Communication, 16(1), 19-39. https://doi.org/10.1177/1742766519900329

Hípola, B. ve Padilla, J. (2020, Haziran 26). Ideology and polarization in times of Coronavirus. Eurocrisis Press. 15 Temuz 2020 tarihinde https://blogs.lse.ac.uk/eurocrisispress/2020/06/26/polarization-coronavirus/ adresinden erişildi.

Katsourides, Y. (2020). Political competition post-covid-19: politıcal change is nothing but certain. IN DEPTH, 17(3) 15 Temuz 2020 tarihinde https://epin.org/wpcontent/uploads/2020/05/newsletter.pdf adresinden erişildi.

Kleinfeld, R. ve Quarcoo, A. (2020, Mayıs 01)) Can the Coronavirus Heal Polarization? Carnegie Endowment For International Peace. 18 Temuz 2020 tarihinde https://carnegieendowment.org/files/QuarcooKleinfeld CoronavirusHealPolarization.pdf adresinden erişildi.

Pastreich, E.(2020, Mart 16). The global media and COVID-19. Foreign Policy in Focus. 15 Temuz 2020 tarihinde https://fpif.org/the-global-media-and-covid-19/ adresinden erişildi.

Rizzi, P. (2020, Mayıs 20).The Post-COVID-19 future of Europe. 15 Temuz 2020 tarihinde https://fordhamobserver.com/46785/opinions/the-post-covid-19-future-of-europe/ adresinden erişildi.

Youngs, R. (2020 Haziran 10. Coronavirus and Europe's New Political Fissures. 18 Temuz 2020 tarihinde https://carnegieeurope.eu/2020/06/10/coronavirus-and-europes-new-political-fissures-pub-82023 adresinden erişildi.

\section{Kaynakça Bilgisi / Citation Information}

Boschele, M. (2020). Küreselleşme paradigması ve COVID 19 krizinde medya üzerine bir değerlendirme. OPUS-Uluslararası Toplum Araştırmaları Dergisi, 16(31), 4430-4444. DOI: 10.26466/opus.795725 